\title{
The Contested Space of Animals in Education: A Response to the "Animal Turn" in Education for Sustainable Development
}

\author{
Helena Pedersen \\ Department of Pedagogical, Curricular and Professional Studies, University of Gothenburg, 40530 Göteborg, \\ Sweden; helena.pedersen@gu.se
}

Received: 31 May 2019; Accepted: 31 July 2019; Published: 8 August 2019

\begin{abstract}
The so-called "animal turn", having been on the agenda for around 15 years in the humanities and social sciences, is gaining force also in the educational sciences, typically with an orientation toward posthumanist ontologies. One particular space where educational "more-than-human" relations are debated is the field of education for sustainable development (ESD). This paper responds to two recent contributions to this debate, both positioned within ESD frameworks. The purpose of this response is two-fold: First, to give a critical account of the knowledge claims of the two articles, their overlaps and divergences, as well as their implications for pedagogical practice and their potential consequences for the position of animals in education and in society at large. The meaning and usefulness of analytic tools such as "critical pluralism" and "immanent critique" in relation to animals in education is discussed, as well as whose realities are represented in ESD, revealing contested spaces of teaching and learning manifested through an "enlightened distance" to anthropocentrism in-between compliance and change. The second purpose is to sketch a foundation of reflective practice for critical animal pedagogies, offering a critical theory-based form of resistance against recent posthumanist configurations of the "animal question" in education and beyond.
\end{abstract}

Keywords: education for sustainable development; animals; posthumanism; anthropocentrism; more-than-human; critical animal pedagogies

\section{Introduction}

Since its relatively recent inception, the notion of the "animal turn" [1,2] has arguably opened up new horizons in the humanities, social, and educational sciences, accompanied by a wave of scholarly attention to what has been termed "more-than-human" [3] worlds, spaces, encounters, and relations (see, for instance, [4-6]). The "more-than-human" in education research usually refers rather sweepingly to nonhuman organisms, ecological entities, and natural phenomena. This paper analyzes implications of addressing human-animal relations as a topic of inquiry in the educational sciences; specifically in the field of education for sustainable development (ESD).

The use of animals in education is deeply embedded in-and has significant implications for-society's relationships with animals more generally [7]. Animals are displayed, classified, studied, and represented, as well as confined, manipulated, consumed, and killed, in a multitude of forms in education [8]. They are incorporated in the science curriculum as carriers of scientific knowledge about laws, conditions, and functions of "nature." For instance, students are implicitly or explicitly taught to utilize, dominate, or control other species as dissection specimens for hands-on training of certain skills in science classrooms, or as other forms of scientific objects in biology and ecology curricula [9]. In non-invasive human-animal pedagogical situations, such as animal-assisted interventions, animals may be used in the classroom for purposes of enhancing children's social, cognitive, or emotional 
development (for instance, improving their reading skills) [8]. Animals are furthermore used in some outdoor education practices, and in study visits to zoos (where their captivity is often normalized and rarely rendered problematic; see [10].) The animal industries also heavily target schools through materials such as films, books, farm visits with free food samples, products in the school cafeteria, advertising, vending machines, sponsorships, and even through offering complete pedagogical plans tailored to fit with the school curriculum and fulfil learning objectives [11-13]. Although educational institutions are not the only societal actors contributing to organizing and forming human-animal relationships, the education system occupies a particular space as norm-(re)producer and legitimizer of certain knowledge forms, social orders, and practices, where animals figure in asymmetrical power arrangements [10]. The way education theory and practice explicitly or implicitly acknowledge the problem of animals in education, thus, has consequences for the life conditions of both animals and humans in and beyond institutionalized settings of teaching and learning, as well as for fraught society/nature demarcations at large. As we shall see, this problem complex is made visible in particular ways in contested spaces of ESD.

Recognizing the wide range of scholarly and scholar-activist work on animals in education (e.g., [11, 13-27]), the present paper provides a critical response to two particular co-authored contributions to the nascent area of animals in ESD research: Bruckner and Kowasch's article "Moralizing meat consumption: Bringing food and feeling into education for sustainable development" [28], and Lindgren and Öhman's article "A posthuman approach to human-animal relationships: advocating critical pluralism" [29]. I consider these two articles as particularly interesting contributions to the debate of animals in education for several reasons. Although published in two different journals and with different methodological orientations (one empirically-based and focusing on ESD in geography and economy-related subject areas; the other concept-driven and addressing cross-curricular educational contexts), they both seek to combine ethics, politics, and posthumanist ontology in their argumentation for the development of a "more-than-human" ESD practice, thereby ontologizing animals in specific ways (I will get back to this toward the end of this article). Furthermore, both articles point to how human-animal relations is never an innocent topic of educational inquiry, but constitutes a profoundly contested terrain (cf. [30]). Without claiming that they are somehow "representative" of scholarship on animals in ESD research, I argue that the articles appear to capture some recent tendencies of the "animal turn" in ESD (as indicated above). My purpose here is first to pursue a critical analysis of the knowledge claims of the two articles, their overlaps and divergences, as well as their implications for pedagogical practice and their potential consequences for the position of animals in and beyond educational settings. My methodological approach is a critical theory-driven comparative analysis of the two articles. While my analysis is not a proper critical discourse analysis in, for instance, a Foucauldian sense, it does accommodate elements of, and asks questions inspired by, critical discourse analysis. Drawing on Patricia MacCormack's [19] work on animal ethics and education, I will then suggest ideas for critical animal pedagogies as an educational counter-movement against certain ways that posthumanist configurations of the "animal question" [31] have been picked up and applied in education research. The arguments pursued in this paper are anchored in a critical animal studies and critical education theory position; both which are in tension with posthumanist ontologies (see, for instance, [32]). This tension will come to the fore in my analysis and be approached as a productive site of reflective practice.

\section{Animals in ESD Research: "Moralizing Meat Consumption" and "A Posthuman Approach to Human-Animal Relationships"}

The notion of education for sustainable development (ESD) is undergoing a conceptual shift to environmental and sustainability education (ESE). I have chosen to use ESD consistently throughout this paper, meaning to include also ESE. ESD as a field of education practice and research is sometimes viewed as a policy-driven successor to environmental education (EE). Although its origins can be traced back to traditions in nature studies and nature conservation education since the late 1800s [33], 
ESD has a relatively brief history largely paralleling the implementation of international policy documents and programs on sustainable development (the Brundtland Report in 1987 by the World Commission on Environment and Development; The United Nations Decade for Education for Sustainable Development 2005-2014; followed by the Global Action Programme on ESD and the Sustainable Development Goals). There are divergent voices within the field, but a core tenet of ESD has unfolded around a critique of its perceived normativity stipulating what sustainable development "is" and how education addressing problems of unsustainability "should" be carried out (see, for instance, [34]). Bruckner and Kowasch [28] (p. 5) even raise a concern that ESD will be "mis-educative" because "pre-determined actions for a specific future reduce possibilities for students to act on their own initiative and develop their own ideas and projects." In a similar vein, Lindgren and Öhman draw on a tradition of a "pluralistic" approach to ESD, driven by a skepticism of an education "that serves a specified end" [29] (p. 1), and that rather promotes an "education of participation" open to conflicting views. From a conventional anthropocentric perspective on education as a democratic and humanistic project, attentive to the multiple voices of students, children, parents, educators, and other (human) actors in society at large, this position appears to make a lot of sense.

With the "animal turn", however, ESD has taken on board yet another stakeholder: The animal subject. While (wild) animals have always been relevant to EE/ESD in their capacity of species representatives and their roles for biodiversity and ecosystem functioning, Spannring [26] has provided a helpful overview on various trajectories through which animals as subjects, rather than as species representatives, have made their way into the ESD field. One of these trajectories is the posthumanist approach, which has proliferated across the humanities and social sciences. With posthumanism, anthropocentrism in education has shifted from being a taken-for-granted normality to, if not an outright bad word, at least a contested position demanding argumentation, reflection, and debate. As a shorthand for manifesting an enlightened distance to anthropocentrism, analytic focus on more-than-human relationships is advocated by an increasing body of scholarship in education and elsewhere, including the two articles addressed here [28,29].

It is in the above roughly outlined conceptual terrain that we find the two articles "Moralizing meat consumption: Bringing food and feeling into education for sustainable development" [28] and "A posthuman approach to human-animal relationships: advocating critical pluralism" [29]. I anticipate that forcing these two different texts together in a critical review may be perceived as enacting a form of discursive violence on both. As indicated above, however, I argue that there are reasons for doing so; reasons that I hope will become clear as my analysis unfolds. I will now take a closer look at the respective knowledge claims of the articles, their lines of argumentation, and their conclusions.

Bruckner and Kowasch's article [28], bringing together food geographies, affect studies, and ESD, is an empirical investigation of how the topic of meat and meat consumption is addressed in geography education in Germany and Austria involving students aged 10-18. Data were produced through geography/economics curricula analyses (comprising eight curricula), a large-scale quantitative survey (comprising 481 student respondents), and qualitative interviews (individual and group interviews) with students, teachers, and also with seven meat-producing farmers from "educational farms"; i.e., farms hosting study visits by school classes. Students participating in group interviews were also asked to draw their perception of "sustainability" (39 drawings were produced). An organizing concept and target of critique throughout the study is "moralizing," approached by the researchers as a "trap" teachers risk falling into [28] (p. 13); that is, an intrinsically problematic aspect of ESD in general (for reasons briefly referred to above), and of meat consumption in education in particular:

Moralizing intensive animal production as 'bad' is a common societal practice yet, for many, addressing intensive farming and animal suffering is far from ticking off a simple sustainability checklist. Furthermore, eating is not a 'rational' process, but an emotional, cultural and metabolic act. Thus, 'critical thinking' alone does not cause students to consider how food from various production systems 'tastes', 'feels' or becomes 'sustainable'. [28] (pp. 5-6) 
Findings of this study indicate that although meat production and consumption is not explicitly mentioned in the geography curricula analyzed, survey data suggest that meat appears as a discussion topic in classrooms. Survey and interview data show, according to the authors, how "moralizing" occurs in relation to meat production and consumption within an ESD context. One geography/economics teacher remarked in an interview that "students already come to school with a 'right-wrong schema'," prompting the teacher to "show students that there is something in between." Moralizing, the researchers argue, promises easy solutions in a reality that is more complex. This sentiment seems to be backed up by the analyses of student drawings, showing a "simplified 'good' versus 'bad' understanding of animal agriculture" with factory farming and organic farming in opposition: "Whereas the farmer from the organic farm appears [in one student's drawing] smiling in overalls, the other carries bags filled with money." [28] (p. 11) On the positive side of this moralizing on the part of students, the authors remark that the drawings "prove that some students do connect meat with animals' lives and consider animal welfare as a key to more sustainable meat." [28] (pp. 11-13).

These results resonate, to some extent, with my own upper secondary classroom ethnographies [10], indicating that some teachers of animal welfare-related topics make great efforts to avoid communicating in the classroom what they perceive as biased, black-and-white representations of reality, and also avoid promoting their own views on human-animal relations (at least when these views are anchored in an animal rights commitment). In Bruckner and Kowasch, the interviews with local meat producers at "educational farms" centered, according to the researchers, "on disconnections between / . . / the meat-consuming public and farm realities." [28] (p. 8) Also this aspect resonates with my empirical studies of veterinary education practice ([7]; cf. [35]), where the notion of "disconnections" becomes a way of neutralizing critique toward the animal production system and downplaying possible antagonistic positions between "the public" and meat producers, indicating that such conflicts can be overcome through public education. We may, for instance, ponder this statement made by a cattle farmer interviewed: "If a consumer is motivated to think about animal welfare, then it's usually negative ... but to consider a better life for the animal, like we aim for on our farm, few consumers understand that." [28] (p. 11) This remark on consumers' perceived lack of understanding of farming reality is, however, not framed in the analysis in terms of "moralizing," which otherwise seems to have guided the interviews and surveys with students and teachers in Bruckner and Kowasch's study [28]. This discrepancy raises a number of methodological questions related to how certain key concepts are used and for what purposes, but perhaps a more significant issue evoked by these examples is whose "reality" is represented in (ESD) education, especially in the case of ESD research advocating "more-than-human" approaches.

At this point, let me shift attention toward the other ESD article of concern here: "A posthuman approach to human-animal relationships: advocating critical pluralism" [29]. This article, in itself a response to another article analyzing the blatant anthropocentrism in pluralistic ESD research traditions [17], resembles Bruckner and Kowasch's [28] contribution above by speaking positively about more-than-human relationalities in education, while at the same time eschewing the idea of moralizing about human-animal relations. This position is made clear already in the introduction of the article: "Our critical pluralist approach does not start in moral or animal rights arguments, but focuses on how the bodies and agency of nonhuman animals can enable humans to act in political and ethical life." [29] (p. 2) Throughout the article, the authors keep reasserting their distance from "idealizing", and thus moralizing, human-animal relationships [29] (pp. 3-4, 9-10), and the problem of animal rights, here flattened out as a (flawed) instantiation of moralization, is re-emphasized further on in the text:

To conclude, what is suggested is a more critical pluralist perspective, where educational practice pays attention to our already existing (and often abusive) entanglement with the more than human world. But when we approach these 'more than human' relationships in education, it does not have to be seen as a linear process that aims to fulfil the ethical demands 
of all nonhuman beings. Instead, these relationships can be approached as contingent and 'characterized by difficulties, contradictions and detours' (Spannring 2017, 8). [29] (p. 11)

The purpose of the article is, thus, to advocate a "critical pluralist approach" that recognizes animal difference (rather than their presumed sameness with humans, here viewed as a problematic "moral-extensionist" vantage point) through an emphasis on animal agency. This line of argumentation is pursued through a theoretically driven discussion, engaging works of ecofeminist (Val Plumwood) and posthumanist feminist (Rosi Braidotti) scholars, as well as empirical examples from other research (including my own). This "critical pluralist approach" seeks to address human-animal power relations and develop an "immanent critique" useful for this purpose. Immanent critique is here put to work not fully adhering to its Hegelian-Marxist origins (to confront existing societal orders with the claims of their own conceptual principles and thus reveal their inherent contradictions), but rather as a didactic practice, to encourage students "to ask who they will become in relation to 'the animal'" [29] (p. 7) and to "'unmask' the underlying ethical, political and ecological dimensions in education." [29] (p. 12) The authors furthermore propose a "stay in conflict" in controversial educational situations addressing the situation of animals in human society on the grounds that "the idea of a predetermined change that automatically would transform conflictual/confrontational views and opinions into consensual agreements is problematic" [29] (p. 10, emphasis in original). Perhaps more remarkably, considering the "more-than-human" claims of this article, "stay in conflict" as an educational approach is motivated by "the impossibility of a consensual agreement over what an abusive treatment of animals really is (Eating meat or drinking milk? Having animals at zoos or use in sports? Animal experimentation? etc.) and how/if education has a responsibility to change this." [29] (p. 10). Although this "stay in conflict" approach seems to differ from Bruckner and Kowasch's [28] emphasis on reconciliation between presumably conflictual positions, the question emerges here as well whose reality is actually taken into consideration, and how the subjects in focus in Lindgren and Öhman's article-presumably the animals—are, at the same time, rendered curiously marginalized (cf. [36]).

Before discussing other key convergences between the two articles, I want to take a brief look at their respective conclusions and recommendations for ESD practice. Bruckner and Kowasch find that although ESD in practice often leads to simplified (moralizing) conceptions of "right" versus "wrong," and that ESD "ignores the interpersonal, relational and more-than-human elements of food systems" [28] (p. 1), students view animal welfare as an important aspect of sustainability. This, according to the researchers, opens opportunities for "making students aware of the visceral (dis)connections they make between taste and political economy" [28] (p. 1). How, then, should this awareness be promoted through education? Bruckner and Kowasch here turn to the literature on emancipatory approaches to ESD, with the aim of assisting students to develop "their own ethics of the gut" [28] (p. 1): a reflective, "nonmoralizing" food practice [28] (p. 14). As inspiration for concrete educational activities ("more-than-human interventions"), they turn to, among others, my work [37]. Considering the context unfolding throughout their article, most of the suggested activities are, however, quite far from anything I would propose: Supermarket visits where students are asked to analyze marketing strategies and plan their own "perfect supermarket" according to their own preferences; blind tasting of food (including "animal welfare"-certified products); study visits to farms, slaughterhouses, butchers, and retailers (representing different stages within the meat-producing system; see $[7,38,39]$ for critical accounts of similar field trips within the veterinary education program); and working in school gardens that keep animals on their premises. The overarching pedagogical idea, as articulated by the authors, is to put "critical thinking, feeling and doing into practice" [28] (p. 14) and move students to "consider animals' lives in noninstrumental ways" [28] (p. 15). The presumed connection(s) between educators' teaching and students' learning (if such a connection exists) is not elaborated on in the article; nor is there any discussion on the implications of these "meat pedagogies" [28] (p. 16) for the actual situation of the animals involved: In this more-than-human approach to ESD, the animals themselves are, again, rendered curiously marginalized [36]. 
In Lindgren and Öhman [29], conclusions are more theoretically-driven than in Bruckner and Kowasch [28], proposing a theoretical framework (critical pluralism) for approaching the "question of the animal" in education. The posthumanist-oriented recommendations for educational practice are based on a recognition of nonhuman (animal) agency (here, the authors refer to the agency of both living and killed animals); i.e., what animals can "do" in educational settings and how they affect teachers and students. In addition, the authors propose developing an "immanent critique" through engaging students in discussions on, for instance, why we treat some animals as worth saving and protecting; others as exploitable in food production systems; the ethical, political, and ecological consequences of the billion dollar pet business; and animals used in zoos and circuses, poaching and hunting, and animal experimentation. Examining "the link between meat consumption and economic growth by asking how different organisations using animals as a commodity consider ethical quandaries or the ecological impact connected with their 'products'" is another suggested example of a classroom activity [29] (p. 11). Such attempts of scrutinizing the animal-industrial complex [40,41] are all necessary components of a critical analysis of human-animal relations in education [8]. In this context, the authors also make an important point, arguing that "environmental educators might ask why some of the most important agents of climate change are overlooked, i.e., cows, chickens and pigs" [29] (p. 12).

However, Lindgren and Öhman conclude with a reservation: "[W]e do not claim that educators can undo all power relations or create educational settings in which we can morally include or speak for all nonhuman species" [29] (p. 12, emphasis in original). Such an ambition is considered altruistic by the authors, and also a way of disregarding "the political and juridical limitations that restrict a majority of educational institutions" [29] (p. 12). While this reservation may appear reasonable, it also "rescues" the position of the human in education on the grounds that it is inescapable and a necessary condition for political and environmental engagement. As a result, the authors propose Braidotti's notion of a "nomadic subject": "[A]n idea of subjectivity that attempts to transcend an essentialist separation between humans and nature and extends the traditional subject-object position" [29] (p. 5, emphasis in original). A nomadic subjectivity is, furthermore, "sensitive to the interplay of ecological destruction and the commodification and capitalisation of animal bodies" [29] (p. 12). Who is supposed to take on board this alternative subjectivity remains, however, somewhat unclear. It is suggested that educators consider it, but if also students and ESD researchers, and possibly other stakeholders in the ESD field are included here is an open question. Nevertheless, proposing a new subjectivity in education seems to be beyond the realms of "moralizing".

\section{Sustaining the Ontologization of Animals-For-Us}

The two ESD articles addressed above, despite their divergent methodological approaches to the "animal question" in education and their different theoretical ambitions, do seem to converge on a number of points. Both claim a space for human-animal relations in ESD and recognize the ethical and political nature of this space; however, both also argue for the importance of this space to be free from any kind of "moralizing" of human-animal relations by educators. Moralizing appears, in both articles, as a discursive tool through which moves toward radical changes in human-animal relationships are blocked. Both rely to some extent on posthumanist scholarship (more in the case of Lindgren and Öhman [29], less in Bruckner and Kowasch [28]). Both also ontologize animals as accessible for human use, particularly as food products:

Perhaps students lack a more nuanced understanding of the links between care, economy, the environment and animal welfare but, nonetheless, they do communicate an interrelation between animal life, meat and sustainability. [28] (p. 13)

Bruckner and Kowasch furthermore propose "bringing students' attention to the visceral, relational ethics of a food system that makes animals into meat" [28] (p. 14), disregarding the fact that the animals are always already ontologized as meat (cf. [42]), and that their own study contributes to reinforcing 
this ontologization. Not entirely surprising, perhaps, considering that the research, according to the authors' own note, is partly supported by an Austrian regional government-funded project entitled "(Un)Knowing Food" [28] (p. 16). On the website, the project is described as follows:

The Project "(Un)Knowing Food" examines the assemblage, circulation, and performance of transparency within the pork and beef industry of Styria, Austria. / . . / The results of the research project will form the basis for collaboration with regional meat producers in Styria, with the aim of transgressing existing boundaries between spaces of consumption and production.

(https://geographie.uni-graz.at/en/research/research-groups/human-geography/humangeography-ii/laufende-projekte/un-knowing-food/, emphasis added)

From the project description above, we can conclude that the "(Un)Knowing Food" project equals food with meat (derived from pigs and cows), altogether excluding plant-based foods. Consequently, the premises of the project, as formulated on the website, do not seem to problematize human consumption of animal bodies, but rather take this normative order for granted. Moreover, the aim of "collaboration with regional meat producers in Styria" expresses an identical rationale as the interviews with meat producers at "educational farms" in the empirical data referred to above, addressing "disconnections between / . . / the meat-consuming public and farm realities" [28] (p. 8). Framed within an ESD context and more-than-human rhetoric of human-animal relationalities and ethics, it is difficult to understand the rationale behind the article as anything else than promotion and support of local meat-producing businesses. This brings an urgent edge to the question of what is being sustained in education for sustainable development (e.g., [43]). It also raises questions about the role of education in general, and ESD in particular, in the animal-industrial complex [7].

If the ontologization of animals as food comes across as quite conspicuous in Bruckner and Kowasch [28], it is less obvious in Lindgren and Öhman [29], as their article does bring forth a critique of animal commodification, instrumentalization, and abuse, as well as the consequences of our contradictory relations with animals in society. However, one of their examples of suggested questions that educators could use to encourage student discussions warrants concern:

Can the human use of animals as living/dead commodities be avoided, or does our ethical considerations/obligations concerning animal subjects and/or bodies change in different cases, such as medical research or cosmetics, industrialised meat, locally produced or non-meat alternatives? [29] (p. 11)

By asking if animal use can be avoided, rather than asking how animal bodies become accessible for our use in the first place, the ontological status of animals for us remains intact-which is exactly what needs to be rendered problematic in an immanent critique of human-animal relations in society and education. Thus, I argue that Lindgren and Öhman's promotion of a critical pluralism with regard to animals in ESD is not only wholly inadequate, but also evacuates the notion of "critical" of its political force. To make my point clear, I cite my book chapter on critical animal studies, co-authored with Vasile Stănescu ([30], cf. [44]):

For us, critical refers not only to engagement with critical theory, but equally a commitment to be critical of anything that purports to study animals and at the same time fails to engage, support, protect and stand with the animal herself. [30] (p. 264, emphasis in original)

Critical pluralism fails to "stand with the animal herself," as this is not its purpose (and I believe the article authors would agree with me on this point). Even if steeped in posthumanist concepts and an enlightened distance to anthropocentrism, critical pluralism, at least in this instantiation, is not a gesture towards a sincere act of solidarity with animals; it is, rather, a commitment to, preoccupation with, and celebration of human subjectivity. It is about staying in conflict, not standing with the animal. It is, in other words, not more-than-human but rather more human; that is, more of what education already is. 


\section{Standing with and Staying Away from the Animal in ESD}

The position of the animal in education may be the product of ages of socialization into a society where animals seem to be forever subordinated and destined for involuntary exposure to human intervention. Drawing on Cary Wolfe's Derridean analysis of the question of the animal [31], education is an institution of speciesism not only enabling, but requiring the sacrifice (or subordination or killing) of the animal in order for the human to achieve his full potential. In a different terminology, education is a set of machines producing profoundly unsafe realities for animals through multiple connections with the animal-industrial complex [7]. Although this order of things is extraordinarily resilient, it is not naturally given, nor is it predetermined. As educators, students, and education researchers, we can withdraw. "Standing with the animal" would then mean, literally and figuratively, "staying away from the animal": A withdrawal from any claims made on them; claims on their bodies, behaviors, lives, and emotions, as well as epistemic claims and urges to extract knowledge from and about them $[19,45])$. On this point, MacCormack's argument (drawing on Michel Serres) aligns with Lindgren and Öhman's [29] critique of the tendency to valorize animals' lives based on their similarity to humans-but the recognition of animal difference, proposed by the same authors as an alternative ethical approach; indeed any kind of categorization of animals-is equally problematic, as it always takes the human as reference point. MacCormack writes:

Theorizing "the" animal through examples of species which will always be through human paradigms, shows the degree of animal use that may seem less or more sinister depending on the pedagogic goal, but that is underpinned with an inevitable system of signification which asks the who, the what, the how, and the why. Information about nonhuman lives leads to evaluation, issues of equivalence, and imposed anthropocentric narratives, not liberty. [19] (p. 15)

If we take this argument seriously, replacing one form of human subjectivity (human supremacy) with another (posthumanist, nomadic subjectivity) is not sufficient (if subjectivities can at all be exchanged in this manner): Rather, we must cease thinking about, acting on, and relating to animals as if their ontological status is for us (cf. [27]).

Celebrating posthumanist entanglement between humans and animals will, thus, not benefit animals, as their "entanglement" with us usually means more dependence, more oppression, and more exposure to human-induced violence. (For an elaborate critique of posthumanism in relation to critical animal studies, see [32].) There are at least two simple ways that will, through reflective practice, make it possible to refuse the social, ontological, and educational position of animal-for-us: One way is, as MacCormack suggests, to refrain from exerting human privilege through the little word NOT-“not enslaving, not cannibalizing, not torturing" [45]. This can further be transformed to an exercise that can be easily practiced by most of us in daily life: Not buying them, not breeding them, not consuming them, not wearing them. Not forcing them, not causing them suffering, not imposing ourselves, and our humanity, upon them, but rather take a step aside to create a possibility for them to prosper on their own conditions $[19,45]$. Another way is to shift pedagogical attention away from the animals and toward human behavior, institutions, and thought regimes that have made our appropriation of animals possible. This would mean retaining a position for the human in education, while at the same time reverting this position. MacCormack frames this attention shift as "the unmaking of man, subjectivity, humanism, anthropocentrism, and cogito" [19] (p. 15). Snaza frames it as a critical analysis of texts that force us to grapple with "how the very idea of 'the human' has led us to misrecognize ourselves and our relations to the world" [25] (p. 50). Sanbonmatsu [44] frames it with the question, what kind of being are we who construct society in this way, on the basis of total denigration and violence toward animal life? In such a pedagogical shift, from the animal toward human behavior, there would be a space for many of Lindgren and Öhman's [29] examples of classroom activities referred to above. To these I would add a critical scrutiny of how education itself, as a particular institution of speciesism [31], has a history of violence toward animals and an embeddedness in the animal-industrial complex [7]. 


\section{Conclusions}

Through a critical comparative analysis of two different, but partly overlapping, positions regarding animals in education, this article has shown how efforts to manifest an "enlightened distance" to anthropocentrism in ESD may work in the opposite direction, establishing human interests firmly at the center of education theory and practice, while rendering animal subjects curiously marginalized. In both texts analyzed here, this happens primarily through taken-for-granted negative connotations of the word "moralizing." The present article may be understood as making a case for restoring, or reclaiming, a "moralizing" in human-animal education that other authors seek to distance themselves from. Although such a reclaiming seems both justified and worthwhile, my main point here is rather to show how moralism is put to work as a discursive tool that effectively blocks radical transformation of human-animal relations in education, ultimately reproducing "animals-for-us" pedagogies.

In contrast to "animals-for-us" pedagogies, moves toward a reflective practice of critical animal pedagogies have been introduced: A practice of learning how to stay away from the animal [19]. In a reflective practice of animals in education, staying away from the animal is at the same time to stand with the animal in ESD (and vice versa), and it is this oscillating between standing with, in solidarity, and staying away from, in gracious withdrawal [19]—not "meat pedagogies" [28] or "critical pluralism" [29] - that would form a conceptual and practical basis of critical animal pedagogies (see $[8,21])$. The dynamic relation between "standing with—staying away from" enables paying attention to, and acting on, both the oppressive structures and arrangements organizing collective animal lives and deaths in human society, as well as the desires and needs of the individual animal under shifting circumstances in any given moment (to the extent that her desires and needs can ever be imagined by humans, which, according to MacCormack, they cannot). The aim of critical animal pedagogies is, thus, not to encourage more interaction or connection with animals in education to find out how they may affect us as teachers and learners; rather, the aim of critical animal pedagogies is to disentangle animals from the demands we make on them, and thereby also to free ourselves from our harm-inflicting behaviors.

This would suggest, through reflective practice, a cessation of relating to animals through our narcissistic preoccupation with animals-for-us. Exploring such trajectories in ESD and beyond, across subject-specific curricula and in age-appropriate manners, implies making immanent critique a foundation and condition for political and environmental engagement in human-animal relations. It could even imply the practice of a different kind of critical pluralism, in the sense of opening education to multiple unthought possibilities of unlearning and re-learning our being in the world as standing with, staying away, and stepping aside.

Funding: This research received no external funding.

Acknowledgments: I thank my anonymous reviewers for their generous feedback. I am also grateful to my colleagues in the ESD Research Group at the Department of Pedagogical, Curricular and Professional Studies, University of Gothenburg, for their helpful comments offered on a draft of this article. Needless to say, any remaining errors are my own.

Conflicts of Interest: The author declares no conflict of interest.

\section{References}

1. Armstrong, P.; Simmons, L. Bestiary: An introduction. In Knowing Animals; Simmons, L., Armstrong, P., Eds.; Brill: Leiden, The Netherlands; Boston, MA, USA, 2007; pp. 1-24.

2. Ritvo, H. On the animal turn. Daedalus 2007, 136, 118-122. [CrossRef]

3. Abram, D. The Spell of the Sensuous: Perception and Language in a More-Than-Human World; Vintage Books: New York, NY, USA, 1997.

4. Blaise, M. Fabricated childhoods: Uncanny encounters with the more-than-human. Discourse Stud. Cult. Politics Educ. 2016, 37, 617-626. [CrossRef]

5. Spannring, R. Ecological Citizenship Education and the Consumption of Animal Subjectivity. Educ. Sci. 2019, 9, 41. [CrossRef] 
6. Watson, G.P.L. Wild Becomings: How the Everyday Experience of Common Wild Animals at Summer Camp Acts as an Entrance to the More-than-Human World. Can. J. Environ. Educ. 2006, 11, 127-142.

7. Pedersen, H. Schizoanalysis and Animal Science Education; Bloomsbury Academic: London, UK; New York, NY, USA, 2019.

8. Gunnarsson Dinker, K.; Pedersen, H. Critical Animal Pedagogies: Re-learning our Relations with Animal Others. In Palgrave International Handbook of Alternative Education; Lees, H.E., Noddings, N., Eds.; Palgrave Macmillan: London, UK, 2016; pp. 415-430.

9. Pedersen, H. Animals and Education Research: Enclosures and Openings. In Undisciplined Animals: Invitations to Animal Studies; Segerdahl, P., Ed.; Cambridge Scholars Publishing: Newcastle upon Tyne, UK, 2011; pp. 11-26.

10. Pedersen, H. Animals in Schools: Processes and Strategies in Human-Animal Education; Purdue University Press: West Lafayette, IN, USA, 2010.

11. Cole, M.; Stewart, K. Our Children and Other Animals: The Cultural Construction of Human-Animal Relations in Childhood; Ashgate: Farnham, UK, 2014.

12. Göransson, M. Ätbara Andra; Makadam Förlag: Göteborg och Stockholm, Sweden, 2017.

13. Rowe, B.D. It IS about Chicken: Chick-fil-A, Posthumanist Intersectionality, and Gastro-Aesthetic Pedagogy. J. Thought 2013, 48, 89-111.

14. Corman, L.; Vandrovcová, T. Radical Humility: Toward a More Holistic Critical Animal Studies Pedagogy. In Defining Critical Animal Studies: An Intersectional Social Justice Approach for Liberation; Nocella, A.J., II, Sorenson, J., Socha, K., Matsuoka, A., Eds.; Peter Lang: New York, NY, USA, 2014; pp. 135-157.

15. Kahn, R. Towards Ecopedagogy: Weaving a Broad-based Pedagogy of Liberation for Animals, Nature, and the Oppressed People of the Earth. J. Crit. Anim. Stud. 2003, 1, 36-53.

16. Kahn, R.; Humes, B. Marching out from Ultima Thule: Critical counterstories of emancipatory educators working at the intersection of human rights, animal rights, and planetary sustainability. Can. J. Environ. Educ. 2009, 14, 179-195.

17. Kopnina, H.; Cherniak, B. Cultivating a Value for Non-Human Interests through the Convergence of Animal Welfare, Animal Rights, and Deep Ecology in Environmental Education. Educ. Sci. 2015, 5, 363-379. [CrossRef]

18. Lloro-Bidart, T.; Banschbach, V.S. (Eds.) Animals in Environmental Education: Interdisciplinary Approaches to Curriculum and Pedagogy; Palgrave Macmillan: Cham, Switzerland, 2019.

19. MacCormack, P. Gracious Pedagogy. J. Curric. Pedagog. 2013, 10, 13-17. [CrossRef]

20. Miller, A. Losing Animals: Ethics and Care in a Pedagogy of Recovery. In Posthumanism and Educational Research; Snaza, N., Weaver, J.A., Eds.; Routledge: New York, NY, USA, 2015; pp. 104-118.

21. Nocella, A.J., II; Drew, C.; George, A.E.; Ketenci, S.; Lupinacci, J.; Purdy, I.; Schatz, J.L. (Eds.) Education for Total Liberation: Critical Animal Pedagogy and Teaching against Speciesism; Peter Lang: New York, NY, USA, 2019.

22. Oakley, J. Guest Editorial: Animality and Environmental Education: Toward an Interspecies Paradigm. Can. J. Environ. Educ. 2011, 16, 8-13.

23. Rice, S. Three Educational Problems: The Case of Eating Animals. J. Thought 2013, 48, 112-126.

24. Rowe, B.D. Understanding Animals-Becoming-Meat: Embracing a Disturbing Education. Crit. Educ. 2011, 2, $1-24$.

25. Snaza, N. Bewildering Education. J. Curric. Pedagog. 2013, 10, 38-54. [CrossRef]

26. Spannring, R. Animals in environmental education research. Environ. Educ. Res. 2017, 23, 63-74. [CrossRef]

27. Wallin, J. Dark Pedagogy. In The Animal Catalyst: Towards Ahuman Theory; MacCormack, P., Ed.; Bloomsbury: London, UK, 2014; pp. 145-162.

28. Bruckner, H.K.; Kowasch, M. Moralizing meat consumption: Bringing food and feeling into education for sustainable development. Policy Futures Educ. 2018. [CrossRef]

29. Lindgren, N.; Öhman, J. A posthuman approach to human-animal relationships: Advocating critical pluralism. Environ. Educ. Res. 2018. [CrossRef]

30. Pedersen, H.; Stănescu, V. Conclusion: Future Directions for Critical Animal Studies. In The Rise of Critical Animal Studies: From the Margins to the Centre; Taylor, N., Twine, R., Eds.; Routledge: London, UK; New York, NY, USA, 2014; pp. 262-276. 
31. Wolfe, C. Animal Rites: American Culture, the Discourse of Species, and Posthumanist Theory; The University of Chicago Press: Chicago, IL, USA; London, UK, 2003.

32. Weisberg, Z. The Trouble with Posthumanism: Bacteria Are People Too. In Critical Animal Studies: Thinking the Unthinkable; Sorenson, J., Ed.; Canadian Scholars' Press: Toronto, ON, Canada, 2014; pp. 93-116.

33. Wals, A.E.J. Learning our way out of unsustainability: The role of environmental education. In The Oxford Handbook of Environmental and Conservation Psychology; Clayton, S.D., Ed.; Oxford University Press: Oxford, UK, 2012; pp. 628-644.

34. Jickling, B. Why I don't want my children to be educated for sustainable development: Sustainable belief. Trumpeter J. Ecosophy 1994, 11, 114-116.

35. Cole, M. From “Animal Machines" to "Happy Meat"? Foucault's Ideas of Disciplinary and Pastoral Power Applied to 'Animal-Centered' Welfare Discourse. Animals 2011, 1, 83-101. [CrossRef]

36. Berger, J. Why Look at Animals? In About Looking; Berger, J., Ed.; Writers and Readers Publishing Cooperative: London, UK, 1980; pp. 1-26.

37. Pedersen, H. Is 'the Posthuman' Educable? On the convergence of educational philosophy, animal studies, and posthumanist theory. Discourse Stud. Cult. Politics Educ. 2010, 31, 237-250. [CrossRef]

38. Pedersen, H. Follow the Judas sheep: Materializing post-qualitative methodology in zooethnographic space. International Journal of Qualitative Studies in Education 2013, 26, 717-731. [CrossRef]

39. Pedersen, H. Parasitic pedagogies and materialities of affect in veterinary education. Emotion, Space and Society 2015, 14, 50-56. [CrossRef]

40. Noske, B. Beyond Boundaries: Humans and Animals; Black Rose Books: Montréal, QC, Canada, 1997.

41. Twine, R. Revealing the 'Animal-Industrial Complex' - A Concept \& Method for Critical Animal Studies? J. Crit. Anim. Stud. 2012, 10, 12-39.

42. Adams, C.J. The Feminist Traffic in Animals. In Ecofeminism: Women, Animals, Nature; Gaard, G., Ed.; Temple University Press: Philadelphia, PA, USA, 1993; pp. 195-218.

43. Kopnina, H. Of big hegemonies and little tigers: Ecocentrism and environmental justice. J. Environ. Educ. 2016, 47, 139-150. [CrossRef]

44. Sanbonmatsu, J. Introduction. In Critical Theory and Animal Liberation; Sanbonmatsu, J., Ed.; Rowman \& Littlefield: Lanham, MD, USA, 2011; pp. 1-32.

45. MacCormack, P. Posthuman Ethics: Embodiment and Cultural Theory; Routledge: Abingdon, UK, 2012.

(C) 2019 by the author. Licensee MDPI, Basel, Switzerland. This article is an open access article distributed under the terms and conditions of the Creative Commons Attribution (CC BY) license (http://creativecommons.org/licenses/by/4.0/). 